\title{
Pengaruh Kecerdasan Emosional dan Disiplin Kerja terhadap Komitmen Karyawan pada PT. X
}

\author{
Vini Tri Susanti*, Rusman Frendika \\ Prodi Manajemen, Fakultas Ekonomi dan Bisnis, Universitas Islam \\ Bandung, Indonesia. \\ *susantivinitri@gmail.com, rusman82@gmail.com
}

\begin{abstract}
Emotional intelligence is a person's ability to know feelings and regulate their emotions in relation to other people, with emotional intelligence in employees, these employees will have a good work discipline attitude, where they will think and control their emotions before doing something, while up to Currently, it cannot be said that employees have good emotional management so that it will be difficult to create self-fitness for work or organization. Based on this phenomenon, the problems in this study are formulated as follows: (1) How is emotional intelligence at PT. X? (2) How is the work discipline at PT. X? (3) How is the commitment of employees at PT. X? (4) How is emotional intelligence on employee commitment at PT. X? (5) How is work discipline towards employee commitment at PT. X? In this study, the method used is descriptive and verification methods, using a quantitative research approach. Data collection techniques used in this study were questionnaires, interviews, observation, and literature study. The population selected in this study were all employees at PT. Shoetown Kasokandel with 4,000 employees. The sampling technique was simple random sampling so that the number of samples obtained was 89 people. The results of this study are: There is an influence between emotional intelligence and work discipline on employee commitment at PT. X.
\end{abstract}

Keywords: Emotional Intelligence, Work Discipline, Employee Commitment

Abstrak. Kecerdasan emosional merupakan kemampuan seseorang dalam mengatahui perasaan dan mengatur emosinya dalam hubungannya dengan orang lain, dengan adanya kecerdasan emosional didalam diri karyawan maka karyawan tersebut akan memiliki sikap disiplin kerja yang baik, dimana mereka akan lebih berfikir dan melakukan kontrol emosinya sebelum melakukan sesuatu, sedangkan hingga saat ini belum dapat dikatakan karyawannya memiliki pengelolaan emosi yang baik sehingga akan sulit tercipta kesesuaian diri terhadap pekerjaan ataupun organisasi. Berdasarkan fenomena tersebut, maka permasalahan dalam penelitian ini dirumuskan sebagai berikut: (1) Bagaimana kecerdasan emosional di PT. X? (2) Bagaimana disiplin Kerja di PT. X? (3) Bagaimana komitmen karyawan di PT. X? (4) Bagaimana kecerdasan emosional terhadap komitmen karyawan pada PT. X? (5) Bagaimana disiplin kerja terhadap komitmen karyawan di PT. X?. Pada penelitian ini metode yang digunakan adalah menggunakan metode deskriptif dan verifikatif, dengan menggunakan pendekatan penelitian kuantitatif. Teknik pengumpulan data yang digunakan dalam penelitian ini adalah kuesioner, wawancara, observasi, dan studi pustaka. Populasi yang dipilih dalam penelitian ini yaitu seluruh karyawan di PT. Shoetown Kasokandel yang berjumlah 4.000 karyawan. Teknik penarikan sampel yaitu simpel random sampling sehingga diperoleh jumlah sampel sebesar 89 orang. Hasil penelitian ini adalah: Terdapat pengaruh antara kecerdasan emosional dan disiplin kerja terhadap komitmen karyawan di PT. X.

Kata Kunci: Kecerdasan Emosional, Disiplin Kerja, Komitmen Karyawan 


\section{A. Pendahuluan}

Komitmen karyawan dapat dikatakan sebagai suatu keadaan seseorang, dimana ia memihak kepada organisasi dan menerima tujuan organisasi, serta berusaha keras untuk tetap menjadi anggota dalam organisasi tempat ia bekerja (Robbins, 2008). Pada kenyataannya semakin sesuainya kepribadian seseorang terhadap pekerjaannya akan semakin besar komitmen karyawan terhadap organisasi, sebab salah satu faktor yang menentukan baik buruknya komitmen karyawan terkait dengan kinerjanya didalam organisasi yaitu kecerdasan emosional yang ada didalam diri para pekerjanya. Kecerdasan emosional menurut (Daniel, 2003) adalah kemampuan seseorang dalam memotivasi dirinya, mengetahui perasaan dan mengatur emosinya dalam hubungannya dengan orang lain.

Karyawan cenderung akan menyesuaikan diri terhadap organisasi dengan melakukan hal-hal yang diharapkan oleh organisasi yang akan terlihat dari tindakan dan perilakunya dalam menjalankan pekerjaan seperti dalam melaksanakan tugas dengan baik bahkan karyawan tersebut semakin loyal dan setia kepada organisasi, serta mereka akan lebih memiliki kemampuan dan kemauan untuk menyeimbangkan antara perilakunya dengan keputusan dan tujuan organisasi, yang mana mereka lakukan dengan adanya control emosi dan pemahaman akan diri sendiri terhadap orang lain, maka dengan demikian akan mudah bagi organisasi untuk menciptakan disiplin kerja yang baik di dalam diri masing-masing karyawan. Faktor lain yang sama pentingnya dalam mempengaruhi komitmen karyawan yaitu disiplin kerja. Disiplin kerja merupakan sikap kesediaan dan kerelaan seseorang untuk mematuhi dan mentaati norma-norma atau peraturan yang berlaku di sekitarnya, serta sebagai alat penggerak bagi karyawan agar setiap pekerjaan yang diberikan dapat dijalankan dengan lancar (Sutrisno, 2009).

Menyeimbangkan antara perilaku dengan lingkungan kerja merupakan hal yang sulit dilakukan, hal tersebut karena sifat emosional yang dimiliki setiap orang berbeda-beda, maka dari itu setiap karyawan perlu dalam mengelola dan mengatur emosional yang dimilikinya secara cermat, untuk dapat mencapai tujuan organisasi yang diinginkan maka perlu adanya campur tangan dari organisasi dan karyawan dalam hal mengarahkan, mengontrol dan membimbing perilaku karyawan dalam menjalankan kegiatannya, sehingga akan dengan mudah menimbulkan rasa tanggung jawab didalam diri para karyawan serta akan lebih loyal terhadap organisasi.

Berdasarkan uraian latar belakang diatas, maka perumusan masalah dalam penelitian ini adalah sebagai berikut: Bagaimana kecerdasan emosional, disiplin kerja dan komitmen karyawan di PT. X? Seberapa besar pengaruh kecerdasan emosional, disiplin kerja terhadap komitmen karyawan di PT. X? Berdasarkan rumusan masalah diatas, maka yang menjadi tujuan pada penelitian ini yaitu sebagai berikut: Untuk mengetahui kecerdasan emosional, disiplin kerja terhadap komitmen karyawan di PT. X, serta untuk mengetahui besarnya pengaruh antara kecerdasan emosional, disiplin kerja, terhadap komitmen karyawan pada PT. X.

\section{B. Metodologi Penelitian}

Peneliti menggunakan metode survey dengan jenis penelitian asosiatif kausal dan menggunakan pendekatan kuantitatif. Populasi yang dipilih dalam penelitian ini adalah seluruh karyawan di PT. X yang berjumlah 4.000 karyawan.

Teknik pengambilan sampel yaitu dengan teknik simpel random sampling sehingga diperoleh jumlah sampel dalam penelitian ini berjumlah 98 karyawan. Dengan teknik pengumpulan data yang digunakan dalam penelitian ini adalah kuesioner, observasi, wawancara dan studi pustaka. Adapun teknik analisis data yang digunakan dalam penelitian ini adalah teknis analisis deskriptif dan verifikatif.

\section{Hasil Penelitian dan Pembahasan}

\section{Uji Validitas}

Teknik korelasi yang digunakan untuk menguji validitas butir pernyataan dalam penelitian ini adalah korelasi Pearson Product Moment pada variabel kecerdasan emosional, disiplin kerja dan komitmen karyawan, dapat dilihat pada tabel dibawah ini:

Tabel 1. Uji Validitas Kecerdasan Emosional 


\begin{tabular}{|c|c|c|c|}
\hline Butir Pertanyaan & $\boldsymbol{r}_{\text {hitung }}$ & $\boldsymbol{r}_{\text {tabel }}$ & Keterangan \\
\hline Item Pernyataan 1 & 0,347 & 0,1671 & Valid \\
\hline Item Pernyataan 2 & 0,442 & 0,1671 & Valid \\
\hline Item Pernyataan 3 & 0,597 & 0,1671 & Valid \\
\hline Item Pernyataan 4 & 0,547 & 0,1671 & Valid \\
\hline Item Pernyataan 5 & 0,495 & 0,1671 & Valid \\
\hline Item Pernyataan 6 & 0,609 & 0,1671 & Valid \\
\hline Item Pernyataan 7 & 0,463 & 0,1671 & Valid \\
\hline Item Pernyataan 8 & 0,566 & 0,1671 & Valid \\
\hline Item Pernyataan 9 & 0,510 & 0,1671 & Valid \\
\hline Item Pernyataan 10 & 0,619 & 0,1671 & Valid \\
\hline Item Pernyataan 11 & 0,501 & 0,1671 & Valid \\
\hline Item Pernyataan 12 & 0,400 & 0,1671 & \\
\hline Iid & & & \\
\hline
\end{tabular}

Sumber: diolah pada tahun 2021

Tabel 2. Uji Validitas Disiplin Kerja

\begin{tabular}{|c|c|c|c|}
\hline Butir Pertanyaan & $\boldsymbol{r}_{\text {hitung }}$ & $\boldsymbol{r}_{\text {tabel }}$ & Keterangan \\
\hline Item Pernyataan 1 & 0,523 & 0,1671 & Valid \\
\hline Item Pernyataan 2 & 0,628 & 0,1671 & Valid \\
\hline Item Pernyataan 3 & 0,563 & 0,1671 & Valid \\
\hline Item Pernyataan 4 & 0,455 & 0,1671 & Valid \\
\hline Item Pernyataan 5 & 0,474 & 0,1671 & Valid \\
\hline Item Pernyataan 6 & 0,408 & 0,1671 & Valid \\
\hline Item Pernyataan 7 & 0,620 & 0,1671 & Valid \\
\hline Item Pertanyaan 8 & 0,375 & 0,1671 & Valid \\
\hline Item Pertanyaan 9 & 0,354 & 0,1671 & Valid \\
\hline
\end{tabular}

Sumber: diolah pada tahun 2021

Tabel 3. Uji Validitas Komitmen Karyawan 


\begin{tabular}{|c|c|c|c|}
\hline Butir Pertanyaan & $\boldsymbol{r}_{\text {hitung }}$ & $\boldsymbol{r}_{\text {tabel }}$ & Keterangan \\
\hline Item Pernyataan 1 & 0,653 & 0,1671 & Valid \\
\hline Item Pernyataan 2 & 0,700 & 0,1671 & Valid \\
\hline Item Pernyataan 3 & 0,706 & 0,1671 & Valid \\
\hline Item Pernyataan 4 & 0,666 & 0,1671 & Valid \\
\hline Item Pernyataan 5 & 0,664 & 0,1671 & Valid \\
\hline
\end{tabular}

Sumber: diolah pada tahun 2021

Berdasarkan tabel di atas terlihat bahwa nilai koefisien korelasi $\left(r_{\text {hitung }}\right)$ dari setiap butir pernyataan lebih besar dari nilai $r_{\text {tabel }}$ 0,1671. Hasil pengujian ini menunjukan bahwa semua butir pernyataan untuk variabel kecerdasan emosional, disiplin kerja dan komitmen karyawan layak (valid) digunakan sebagai alat ukur penelitian serta dapat digunakan untuk analisis selanjutnya.

\section{Uji Reliabilitas}

Pengujian reliabilitas dilakukan dengan cara menguji coba instrument sekali saja, kemudian dianalisis dengan menggunakan metode alpha cronbach's.

Tabel 4. Hasil Uji Validitas

\begin{tabular}{|c|c|c|c|}
\hline Variabel & Cronbach's Alpha & Nilai R Kritis & Keterangan \\
\hline Kecerdasan Emosional & 0,807 & 0.6 & Reliabel \\
\hline Disiplin Kerja & 0,697 & 0.6 & Reliabel \\
\hline Komitmen Karyawan & 0,702 & 0.6 & Reliabel \\
\hline
\end{tabular}

Sumber: diolah pada tahun 2021

Berdasarkan hasil pengujian validitas dan reliabilitas dapat disimpulkan bahwa seluruh pernyataan yang digunakan sudah teruji kesahihan (validity) serta konsistensinya (reliability) untuk dapat digunakan sebagai alat ukur penelitian

Analisis Deskriptif

Tabel 5. Rekapitulasi Kecerdasan Emosional

\begin{tabular}{|c|c|c|c|}
\hline Variabel & Dimensi & Rata-Rata Skor & Kategori \\
\hline Kecerdasan & Kesadaran diri & 4,18 & Baik \\
\cline { 2 - 4 } Emosional & Pengaturan Diri & 4,09 & Baik \\
\cline { 2 - 4 } & Motivasi & 4,18 & Baik \\
\cline { 2 - 4 } & Empati & 4,01 & Baik \\
\cline { 2 - 4 } & Keterampilan sosial & 4,16 & Baik \\
\hline \multicolumn{2}{|c|}{ Rata-Rata Skor } & $\mathbf{4 , 1 2}$ & Baik \\
\hline
\end{tabular}

Sumber: diolah pada tahun 2021

Berdasarkan tabel rekapitulasi diatas, dapat disimpulkan bahwa secara keseluruhan tanggapan responden mengenai variabel kecerdasan emosional termasuk dalam kategori baik karena memiliki nilai rata-rata sebesar 4,12. Hasil tersebut mengindikasikan bahwa sebagaian besar karyawan di PT. X memiliki kecerdasan emosional yang baik.

Tabel 6. Rekapitulasi Disiplin Kerja 


\begin{tabular}{|c|c|c|c|}
\hline Variabel & Dimensi & Rata-Rata Skor & Kategori \\
\hline $\begin{array}{c}\text { Disiplin } \\
\text { Kerja }\end{array}$ & $\begin{array}{c}\text { Mematuhi semua peraturan } \\
\text { organisasi }\end{array}$ & 4,41 & Sangat Baik \\
\cline { 2 - 4 } & Penggunaan waktu secara efektif & 4,01 & Baik \\
\cline { 2 - 4 } & $\begin{array}{c}\text { Tanggung jawab dalam pekerjaan } \\
\text { dan tugas }\end{array}$ & 4,00 & Baik \\
\cline { 2 - 4 } & Absensi & 3,94 & Baik \\
\hline
\end{tabular}

Sumber: diolah pada tahun 2021

Berdasarkan tabel rekapitulasi diatas, dapat disimpulkan bahwa secara keseluruhan tanggapan responden mengenai variabel disiplin kerja termasuk dalam kategori baik karena memiliki nilai rata-rata sebesar 4,09. Hasil tersebut mengindikasikan bahwa sebagaian besar karyawan di PT. X memiliki disiplin kerja yang baik.

Tabel 7. Rekapitulasi Komitmen Karyawan

\begin{tabular}{|c|c|c|c|}
\hline Variabel & Dimensi & Rata-Rata Skor & Kategori \\
\hline \multirow{3}{*}{ Komitmen Karyawan } & Kemauan Karyawan & 4,33 & Sangat Baik \\
\cline { 2 - 4 } & Kesetiaan Karyawan & 4,31 & Sangat Baik \\
\cline { 2 - 4 } & Kebanggaan Karyawan & 4,10 & Baik \\
\hline \multicolumn{2}{|r|}{ Rata-Rata Skor } & $\mathbf{4 , 2 4}$ & Sangat Baik \\
\hline
\end{tabular}

Sumber: diolah pada tahun 2021

Berdasarkan tabel rekapitulasi diatas, dapat disimpulkan bahwa secara keseluruhan tanggapan responden mengenai variabel komitmen karyawan termasuk dalam kategori sangat baik karena memiliki nilai rata-rata sebesar 4,24. Hasil tersebut mengindikasikan bahwa sebagaian besar karyawan di PT. X memiliki komitmen karyawan yang baik.

Analisi Pengujian Hipotesis

Sebelum melakukan pengolahan data untuk mengukur tingkat pengaruh, maka data hasil kuisioner harus diubah terlebih dahulu menjadi data interval melalui transformasi data dengan MSI (Method Succesive Interval).

\section{Uji Korelasi}

Tabel 10. Hasil Uji Korelasi Kecerdasan Emosional dan Disiplin Kerja Terhadap Komitmen Karyawan

\begin{tabular}{|l|l|c|c|c|}
\hline \multicolumn{4}{|c|}{ Correlations } \\
\hline \multirow{2}{*}{$\begin{array}{c}\text { Kecerdasan } \\
\text { Emosional }\end{array}$} & $\begin{array}{c}\text { Kecerdasan } \\
\text { Emosional }\end{array}$ & Disiplin Kerja & $\begin{array}{c}\text { Komitmen } \\
\text { Karyawan }\end{array}$ \\
\cline { 2 - 5 } & Sig (2-tailed) & 1 &, $552^{* *}$ &, $591^{* *}$ \\
\cline { 2 - 5 } & $\mathrm{N}$ & 98 &, 000 &, 000 \\
\hline \multirow{3}{*}{ Disiplin Kerja } & Person Correlation &, $552^{* *}$ & 98 & 98 \\
\cline { 2 - 5 } & Sig (2-tailed) &, 000 & 1 &, $650^{* *}$ \\
\cline { 2 - 5 } & $\mathrm{N}$ & 98 & 98 & 98 \\
\hline \multirow{2}{*}{$\begin{array}{l}\text { Komitmen } \\
\text { Karyawan }\end{array}$} & Person Correlation &, $591^{* *}$ &, $650^{* *}$ & 1 \\
\cline { 2 - 5 } & Sig (2-tailed) &, 000 &, 000 & 98 \\
\cline { 2 - 5 } & $\mathrm{N}$ & 98 & 98 & \\
\hline
\end{tabular}

Sumber diolah dengan menggunakan SPSS Versi 25

Berdasarkan tabel output di atas terlihat bahwa nilai koefisien korelasi yang diperoleh seluruhnya memiliki nilai bertanda positif dengan nilai signifikansi $0,000<0,05$ yang menunjukkan bahwa hubungan yang terjadi antara variabel bebas dengan variabel 
terikat adalah searah atau semakin baik kecerdasan emosional dan disiplin kerja akan diikuti semakin meningkatnya komitmen karyawan.

Uji Persamaan Regresi Sederhana

Tabel 11. Hasil Uji Persamaan Regresi Sederhana Kecerdasan Emosional Terhadap Komitmen Karyawan

\begin{tabular}{|c|c|c|c|c|c|c|c|}
\hline \multicolumn{8}{|c|}{ Coefficients } \\
\hline Model & $\begin{array}{l}\text { Unstand- } \\
\text { ardized } \\
\text { B }\end{array}$ & $\begin{array}{l}\text { Coeffici- } \\
\text { ents } \\
\text { Std. Error }\end{array}$ & $\begin{array}{l}\text { Standar- } \\
\text { dized } \\
\text { Coefficients } \\
\text { Beta }\end{array}$ & $\mathrm{T}$ & Sig. & $\begin{array}{c}90.0 \% \\
\text { Confidence } \\
\text { Lower } \\
\text { Bound }\end{array}$ & $\begin{array}{c}\text { Interval } \\
\text { B Upper } \\
\text { Bound }\end{array}$ \\
\hline Constant & 7,427 & 2,395 & & 3,101 & ,003 & 3,449 & 11,405 \\
\hline $\begin{array}{l}\text { Kecerdasan } \\
\text { Emosional }\end{array}$ & 246 & 0,34 & ,591 & 7,178 & ,000 & 189 & ,302 \\
\hline
\end{tabular}

Sumber diolah dengan menggunakan SPSS Versi 25

Berdasarkan hasil output di atas dapat diketahui nilai constant dan koefisien regresi yaitu dengan melihat kolom Unstandardized $\mathrm{B}$, sehingga diperoleh persamaan sebagai berikut:

$$
\mathrm{Y}=7,427+0,246 \mathrm{X}
$$

Dari hasil persamaan regresi sederhana tersebut masing-masing variabel dapat diinterpretasikan sebagai berikut:

1. Constant (a) sebesar 7,427 menunjukkan bahwa jika nilai kecerdasan emosional sama dengan nol (0) maka komitmen karyawan akan bernilai sebesar 7,427 dengan kata lain jika kecerdasan emosional sangat rendah maka komitmen karyawan cenderung buruk.

2. Koefisien regresi (b) bernilai positif sebesar 0,246 menunjukkan bahwa setiap bertambahnya nilai variabel kecerdasan emosional sebesar 1 maka variabel komitmen karyawan akan mengalami peningkatan sebesar 0,246. Artinya semakin tinggi kecerdasan emosional maka kecenderungan komitmen karyawan semakin tinggi.

Tabel 12. Hasil Uji Persamaan Regresi Sederhana Disiplin Kerja Terhadap Komitmen Karyawan

\begin{tabular}{|l|c|c|c|c|c|c|c|}
\hline \multicolumn{7}{|c|}{ Coefficients } \\
\hline Model & $\begin{array}{c}\text { Unstan } \\
\text { d- } \\
\text { ardized } \\
\text { B }\end{array}$ & $\begin{array}{c}\text { Coeffici- } \\
\text { ents } \\
\text { Std. Error }\end{array}$ & $\begin{array}{c}\text { Standar- } \\
\text { dized } \\
\text { Coefficients } \\
\text { Beta }\end{array}$ & T & $\begin{array}{c}\text { Sig. } \\
\begin{array}{c}90.0 \% \\
\text { Confide- } \\
\text { nce Lower } \\
\text { Bound }\end{array}\end{array}$ & $\begin{array}{c}\text { Interval } \\
\text { B } \\
\text { Upper } \\
\text { Bound }\end{array}$ \\
\hline Constant & 4,257 & 2,431 &, 650 & 8,377 & $\begin{array}{c}1,00 \\
0\end{array}$ &, 385 &, 575 \\
\hline $\begin{array}{l}\text { Disiplin } \\
\text { Kerja }\end{array}$ &, 480 &, 057 & & 298 &, 219 \\
\hline
\end{tabular}

Sumber diolah dengan menggunakan SPSS Versi 25

Berdasarkan hasil output di atas dapat diketahui nilai constant dan koefisien regresi yaitu dengan melihat kolom Unstandardized B, sehingga diperoleh persamaan sebagai berikut:

$$
\mathrm{Y}=\mathbf{4 , 2 5 7}+\mathbf{0 , 4 8 0} \mathrm{X}
$$

Dari hasil persamaan regresi sederhana tersebut masing-masing variabel dapat diinterpretasikan sebagai berikut:

1. Constant (a) sebesar 4,257 menunjukkan bahwa jika nilai disiplin kerja sama dengan nol (0) maka komitmen karyawan akan bernilai sebesar 4,257 dengan kata lain jika disiplin kerja sangat rendah maka komitmen karyawan cenderung buruk.

2. Koefisien regresi (b) bernilai positif sebesar 0,480 menunjukkan bahwa setiap 
bertambahnya nilai variabel disiplin kerja sebesar 1 maka variabel komitmen karyawan akan mengalami peningkatan sebesar 0,480. Artinya semakin tinggi disiplin kerja

\section{Uji T} maka kecenderungan komitmen karyawan semakin tinggi.

Tabel 13. Hasil Uji T

\begin{tabular}{|l|c|c|c|c|c|c|c|}
\hline \multicolumn{1}{|c|}{ Coefficients } \\
\hline Model & $\begin{array}{c}\text { Unstandardized } \\
\text { B }\end{array}$ & $\begin{array}{c}\text { Coeffici- } \\
\text { ents } \\
\text { Std. Error }\end{array}$ & $\begin{array}{c}\text { Standar- } \\
\text { dized } \\
\text { Coefficients } \\
\text { Beta }\end{array}$ & T & Sig. & $\begin{array}{c}90.0 \% \\
\text { Confidence } \\
\text { Lower } \\
\text { Bound }\end{array}$ & $\begin{array}{c}\text { Interval } \\
\text { B } \\
\text { Upper } \\
\text { Bound }\end{array}$ \\
\hline (Constant) &, 340 & 2,492 & &, 136 &, 892 & $-3,800$ & 4,479 \\
\hline $\begin{array}{l}\text { Kecerdasan } \\
\text { Emosional }\end{array}$ &, 139 & 0,36 &, 334 & 3,840 &, 000 &, 079 &, 199 \\
\hline Disiplin Kerja &, 344 &, 064 &, 465 & 5,349 &, 000 &, 237 &, 451 \\
\hline
\end{tabular}

a. Dependent Variable: Komitmen Karyawan

Sumber diolah dengan menggunakan SPSS Versi 25

Berdasarkan tabel diatas dapat dilihat bahwa nilai $t_{\text {hitung }}$ yang diperoleh adalah sebesar 3,840 , kemudian nilai tersebut akan dibandingkan dengan nilai $t_{\text {tabel }}$ sebesar 1,661. Dapat dilihat pada tabel diatas bahwasannya nilai Sig untuk pengaruh Kecerdasan Emosional $\left(\mathrm{X}_{1}\right)$ terhadap Komitmen Karyawan (Y) adalah sebesar 0,000 $<0,05$ dan nilai $t_{\text {hitung }} 3,840>t_{\text {tabel }}$ 1,661. Sehingga dapat disimpulkan bahwa Ho ditolak dan Ha diterima, artinya bahwa terdapat pengaruh kecerdasan emosional $\left(\mathrm{X}_{1}\right)$ terhadap komitmen karyawan $(\mathrm{Y})$. Pernyataan tersebut sejalan dengan hasil penelitian yang dilakukan oleh (Asrul, 2021) yang menyatakan bahwa hipotesis Ho ditolak dan Ha diterima artinya kecerdasan emosional dan disiplin kerja berpengaruh signifikan terhadap kinerjan karyawan sebagai bentuk komitmen di PT. Radar Sulteng. Lebih jelasnya dapat dilihat pada grafik dibawah ini:

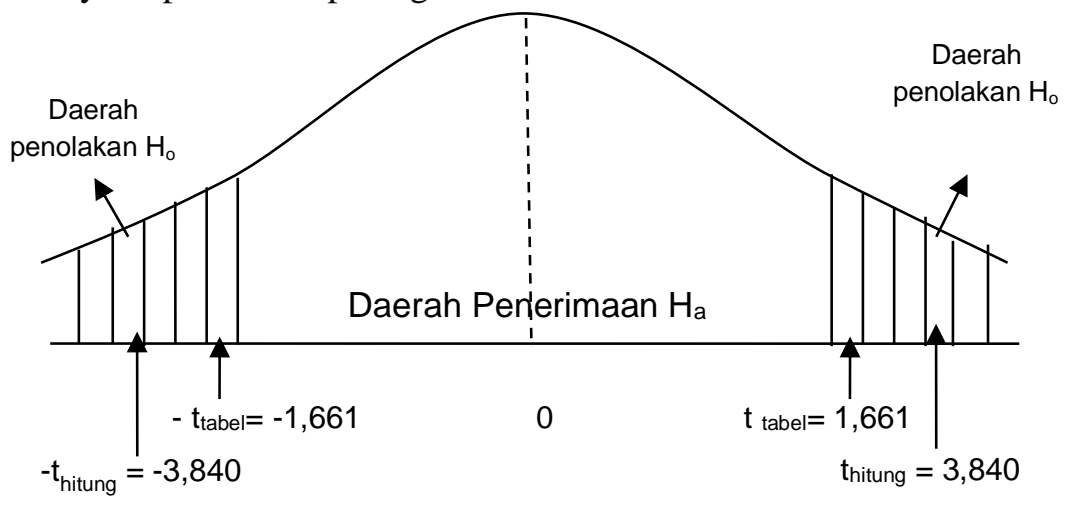

Gambar 1. Uji T Kecerdasan Emosional Terhadap Komitmen Karyawan

Berdasarkan tabel diatas dapat dilihat bahwa nilai $t_{\text {hitung }}$ yang diperoleh adalah sebesar 5,349 , kemudian nilai tersebut akan dibandingkan dengan nilai $t_{\text {tabel }}$ sebesar 1,661. Dapat dilihat pada tabel diatas bahwasannya nilai Sig untuk pengaruh Disiplin Kerja $\left(\mathrm{X}_{2}\right)$ terhadap Komitmen Karyawan (Y) adalah sebesar 0,000 $<0,05$ dan nilai $t_{\text {hitung }} 5,349>t_{\text {tabel }} 1,661$. Sehingga dapat disimpulkan bahwa Ho ditolak dan Ha diterima, artinya bahwa terdapat pengaruh disiplin kerja $\left(\mathrm{X}_{2}\right)$ terhadap komitmen karyawan $(\mathrm{Y})$. Pernyataan tersebut sejalan dengan hasil penelitian yang dilakukan oleh (Zainul Hidayat, 2012) yang menyatakan bahwa hipotesis Ho ditolak dan Ha diterima artinya lingkungan kerja, disiplin kerja dan motivasi kerja berpengaruh signifikan terhadap kinerja karyawan. Lebih jelasnya dapat dilihat pada grafik 
dibawah ini:

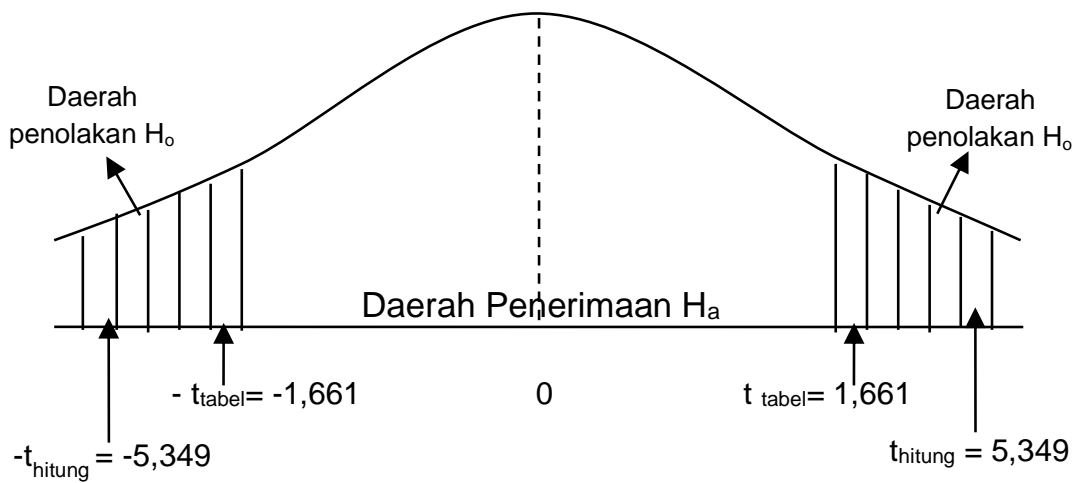

Gambar 2. Uji T Disiplin Kerja Terhadap Komitmen Karyawan

\section{Uji Persamaan Regresi Berganda}

Tabel 14. Uji Persamaan Regresi Berganda Kecerdasan Emosional dan Disiplin Kerja Terhadap Komitmen Karyawan

\begin{tabular}{|l|c|c|c|c|c|c|c|}
\hline \multicolumn{1}{|c|}{ Coefficients } \\
\hline Model & $\begin{array}{c}\text { Unstandardized } \\
\text { B }\end{array}$ & $\begin{array}{c}\text { Coeffici- } \\
\text { ents } \\
\text { Std. Error }\end{array}$ & $\begin{array}{c}\text { Standar- } \\
\text { dized } \\
\text { Coefficients } \\
\text { Beta }\end{array}$ & T & Sig. & $\begin{array}{c}90.0 \% \\
\text { Confide- } \\
\text { nce Lower } \\
\text { Bound }\end{array}$ & $\begin{array}{c}\text { Interval } \\
\text { B } \\
\text { Upper } \\
\text { Bound }\end{array}$ \\
\hline (Constant) &, 340 & 2,492 & &, 136 &, 892 & $-3,800$ & 4,479 \\
\hline $\begin{array}{l}\text { Kecerdasan } \\
\text { Emosional }\end{array}$ &, 139 & 0,36 &, 334 & 3,840 &, 000 &, 079 &, 199 \\
\hline Disiplin Kerja &, 344 &, 064 &, 465 & 5,349 &, 000 &, 237 &, 451 \\
\hline
\end{tabular}

a. Dependent Variable: Komitmen Karyawan

Sumber diolah dengan menggunakan SPSS Versi 25

Berdasarkan hasil output di atas dapat diketahui nilai constant dan koefisien regresi, sehingga diperoleh persamaan berganda sebagai berikut:

$$
Y=0,340+0,139 X_{1}+0,344 X_{2}
$$

Persamaan di atas dapat diartikan sebagai berikut:

1. $\mathrm{b}_{0}=0,340$ artinya jika variabel $\mathrm{X}_{1}$ (Kecerdasan emosional) dan $\mathrm{X}_{2}$ (Komitmen Karyawan) bernilai nol (0), maka variabel Y (Kinerja karyawan) akan bernilai 0,340 satuan.

2. $b_{1}=0,139$ artinya jika Kecerdasan emosional $\left(X_{1}\right)$ meningkat sebesar satu satuan dan variabel lainnya konstan, maka variabel Komitmen Karyawan (Y) akan meningkat sebesar 0,139 satuan.

3. $b_{2}=0,344$ artinya jika Disiplin Kerja $\left(X_{2}\right)$ meningkat sebesar satu satuan dan variabel lainnya konstan, maka variabel Komitmen Karyawan (Y) akan meningkat sebesar 0,344 satuan.

Uji F

Tabel 15. Hasil Uji F

\begin{tabular}{|l|l|c|c|c|c|c|}
\hline \multicolumn{9}{|c|}{ Anova } \\
\hline \multirow{2}{*}{1.} & Model & Sum of Squares & Df & Mean Square & F & Sig. \\
\cline { 2 - 7 } & Regression & 400,999 & 2 & 200,499 & 47,477 &, $000^{\mathrm{b}}$ \\
\hline
\end{tabular}




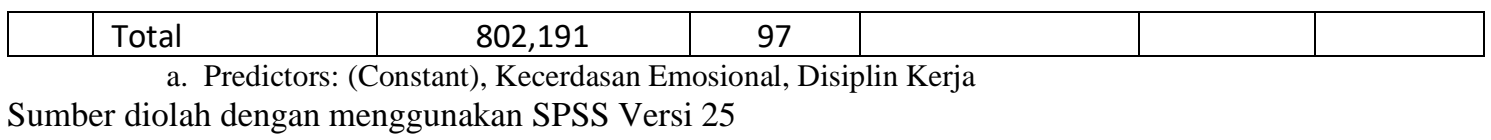

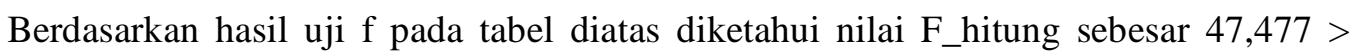
F_tabel 2,14 dengan nilai signifikansi ,000 $<0,05$. Maka dapat disimpulkan H0 ditolak, artinya variabel kecerdasan emosional dan disiplin kerja secara bersama-sama berpengaruh signifikan terhadap komitmen karyawan.

Analisis Koefisien Determinasi

Uji koefisien determinasi berfungsi untuk mengetahui berapa persen pengaruh yang diberikan variabel $\mathrm{X}$ secara simultan terhadap variabel $\mathrm{Y}$.

Tabel 16. Koefisien Determinasi

\begin{tabular}{|c|c|c|c|c|}
\hline \multicolumn{4}{|c|}{ Model Summary } \\
\hline Model & $\mathrm{R}$ & R Square & Adjusted R Square & Std. Error of the Estimate \\
\hline 1. &, $707^{\mathrm{a}}$ &, 500 &, 489 & 2,055013 \\
\hline
\end{tabular}

a. Predictors: (Constant), Disiplin Kerja, Kecerdasan Emosional

Sumber diolah dengan menggunakan SPSS Versi 25

Berdasarkan tabel di atas diperoleh informasi bahwa $\mathrm{R}$ (korelasi) sebesar 0.707

Koefisien Determinasi $=\mathrm{R}^{2}$ X $100 \%$

$$
=(0.707)^{2} \times 100 \%=50 \%
$$

Berdasarkan perhitungan di atas maka dapat disimpulkan bahwa kontribusi pengaruh Kecerdasan Emosional dan Disiplin Kerja Terhadap Komitmen Karyawan sebesar 50\%. Sedangkan sisanya sebesar 50\% merupakan pengaruh dari variabel lain yang tidak diteliti, yaitu kepuasan kerja, lingkungan kerja, dan lain-lain.

\section{Kesimpulan}

Dari hasil penelitian mengenai "Pengaruh Kecerdasan Emosional dan Disiplin Kerja Terhadap Komitmen Karyawan pada PT. X", maka ditaarik kesimpulan sebagai berikut:

1. Kecerdasan emosional karyawan PT. X termasuk kategori baik, hal tersebut dapat terlihat pada dimensi kesadaran diri dan motivasi dengan skor rata-rata tertinggi dibandingkan dimensi yang lain yaitu sebesar 4,18, dimana sebagian karyawan memang memiliki pemahaman diri yang baik serta memiliki motivasi dan ketertarikan untuk bekerja dengan menghasilkan ide-ide yang baru.

2. Disiplin kerja karyawan PT. X termasuk kategori baik, hal tersebut dapat telihat pada dimensi mematuhi semua peraturan organisasi dengan skor rata-rata tertinggi dibandingkan dimensi yang lain yaitu sebesar 4,41. Dimana sebagian karyawan mematuhi semua peraturan organisasi salah satunya mampu mempertanggung jawabkan hasil kerjanya kepada organisasi.

3. Komitmen karyawan PT. X termasuk dalam kategori sangat baik, hal tersebut dapat terlihat pada dimensi kemauan karyawan dengan skor rata-rata tertinggi dibandingkan dimensi yang lain yaitu sebesar 4,33. Dimana sebagian karyawan selalu berusaha berusaha untuk berkinerja sesuai dengan yang diharapkan oleh organisasi, kemauan serta inisiatifnya untuk memberikan hasil yang terbaik kepada organisasi.

4. Kecerdasan emosional berpengaruh terhadap komitmen karyawan PT. X. Hal ini dapat terlihat dari nilai $t_{\text {hitung }}>t_{\text {tabel }}$ atau 3,840 $>1,661$ dengan nilai signifikansi sebesar $0,000<0,05$. Dengan demikian dapat dikatakan bahwa Ho ditolak dan Ha diterima.

5. Disiplin kerja berpengaruh terhadap komitmen karyawan PT. X. Hal ini dapat terlihat dari nilai $t_{\text {hitung }}>t_{\text {tabel }}$ atau 5,349 > 1,661 dengan nilai signifikansi sebesar 0,000< 0,05. Dengan demikian dapat dikatakan bahwa Ho ditolak dan Ha diterima.

6. Kecerdasan emosional dan disiplin kerja berpengaruh positif dan signifikan terhadap komitmen karyawan PT. X. Hal ini dapat terlihat dari nilai $F_{\text {hitung }}>F_{\text {tabel }}$ atau 47,477 $>2,14$ dengan nilai signifikansi sebesar $0,000<0,05$. Dengan demikian dapat dikatakan 
bahwa Ho ditolak dan Ha diterima.

\section{Daftar Pustaka}

[1] Asrul, J. H. (2021). Pengaruh Kecerdasan Emosional dan Disiplin Kerja Terhadap Kinerja Karyawan PT. Radar Sulteng. Jurnal Ilmu Manajemen, 7(3), 258-267.

[2] Daniel, G. (2003). Emotional Intelligence: Mengapa EL lebih penting dari IQ. Jakarta: PT. Gramedia Pustaka Utama.

[3] Ghozali, I. (2016). Aplikasi Analisis Multivariete Dengan Program (IBM SPSS). Semarang: Badan Penerbit Universitas Diponegoro.

[4] Robbins, S. \&. (2008). Organizational Behavior. Jakarta: Salemba Empat.

[5] Sutrisno, E. (2009). Manajemen Sumber Daya Manusia. Jakarta: Kencana Prenada Media Group.

[6] Zainul Hidayat, M. \&. (2012). Pengaruh Lingkungan Kerja dan Disiplin Kerja serta Motivasi Kerja Terhadap Kinerja Karyawan Perusahaan Daerah Air Minum (PDAM) Kabupaten Lumajang. Jurnal WIGA, 2(1), 79-97. 